\title{
PERCUTANEOUS VS SURGICAL TRACHEOSTOMY: AN INCIDENCE RATE OF STOMA INFECTION IN THE NEUROSURGERY ICU OF THE SINGLE TERTIARY LEVEL HOSPITAL
}

\author{
Neringa Balčiūniene் ${ }^{1}$, Oresta Kriukelyté ${ }^{2}$ Jurgita Ramšaite் ${ }^{2}$, Asta Krikščionaitienè ${ }^{1}$, \\ Tomas Tamošuitis ${ }^{1}$ \\ ${ }^{1}$ Department of Neurosurgery, Medical Academy, Lithuanian University of Health Sciences, \\ Kaunas, Lithuania, \\ ${ }^{2}$ Faculty of Medicine, Medical Academy, Lithuanian University of Health Sciences, \\ Kaunas, Lithuania
}

Key words: tracheostomy, percutaneous dilatational tracheostomy, stoma infection, intensive care.
Summary
Objective. The aim of our study was to evaluate and compare the incidence rate of stoma infection af- ter tracheostomy according to the type of procedu- re: percutaneous dilatational tracheostomy (PDT) vs surgical tracheostomy (ST) in Neurosurgery Inten- sive Care Unit (NICU) patients.
Material and methods. We performed a single-cen- ter observational, retrospective cohort study inclu- ding patients who underwent tracheostomy during their stay in the NICU at 2200 bed university te- aching hospital from October 2012 to December 2015. In total 240 patients were identified, the data from 202 patients (140 males) with median age 60 (19-80) who met the inclusion criteria were used for further analysis. There were 84 patients in PDT group and 118 patients in ST group.
Results. The incidence rate of stoma infection was significantly lower in PDT group compared to ST group: $14(16.7 \%)$ vs. $77(65.3 \%), \mathrm{p}<0.001$. The regression analysis showed that the use of ST was associated with an increase in the risk of stoma in- fection $(\mathrm{OR}=8.83 ; 95 \%$ CI 4.40-17.71; $\mathrm{p}<0.001)$.
Conclusion. The incidence rate of stoma infection was significantly higher in ST group compared to PDT group in NICU patients. ST strategy was asso- ciated with increased probability for stoma infection compared to PDT.

\section{Introduction}

Tracheostomy is a priority procedure for critically ill patients who need long term mechanical ventilation or upper airway protection [1]. Formation of the tracheostomy became a suitable alternative to long term intubation to improve patient's comfort, to reduce the need for sedation and airway resistance $[2,3]$. There are two main strategies used for tracheostomy formation: open standard surgical tracheostomy (ST) and bedside percutaneous dilatational tracheostomy (PDT) [4-6]. PDT is an increasingly popular tracheostomy approach in critically ill adults with a similar intraprocedural safety profile as ST [7, 8]. Many studies compare both strategies in terms of complications rate [711]. However, despite tracheostomy procedure frequency, the strategy of choice is unclear and controversial opinion still exist which method is a better option for special groups of critically ill patients $[12,13]$. The data about the complication rate and method of choice for NICU patients are also lacking.

One third of all patients undergo standard open ST or bedside PDT in Neurosurgery Intensive Care Unit (NICU) of Hospital of Lithuanian University of Health Sciences (LUHS) Kauno clinics. Since 2012, when PDT has been implemented in NICU, we noticed that stoma infection has a tendency to develop more in patients with performed standard ST than in patients with performed bedside PDT.

The aim of this study was to identify the incidence rate of stoma infection after tracheostomy according to the type of procedure (PDT versus ST) in NICU patients. 


\section{Material and methods}

Study design. This is a single-center observational, retrospective cohort study.

Patient population and setting. We performed a retrospective chart review of all 240 patients, who underwent tracheostomy procedure during their stay in 18-bed NICU of LUHS hospital Kauno clinics, a tertiary teaching hospital from October 2012 to December 2015. The study was approved by the Local Bioethics Committee of the Lithuanian University of Health Sciences (BEC-MF-220).

Inclusion and exclusion criteria. Inclusion criteria were: NICU patients with age $>18$ and $\leq 80$ who needed prolonged mechanical ventilation (for $\geq 10$ days). Exclusion criteria were: known infection of tracheostomy site, retracheostomy, patients not connected to mechanical ventilation (MV) before tracheostomy.

Tracheostomy procedures. The decision about tracheostomy for the individual patient was made by the patient management team. All patients were laboratory evaluated and clinically examined by intensive care physician before the procedure. Anatomical limitations of neck (short neck), presence of a pulsatile artery or enlarged thyroid gland over the surgical area, inability to identify the cricoid cartilage were contraindications to perform PDT. If contraindications were detected, open ST using standard approach was performed in operating room by otolaryngologist. If no contraindications were detected, bedside PDT was performed by NICU team led by intensive care doctor. We used single-stage dilator technique without the aid of bronchoscope and a standardized equipment (Ultra perc.,

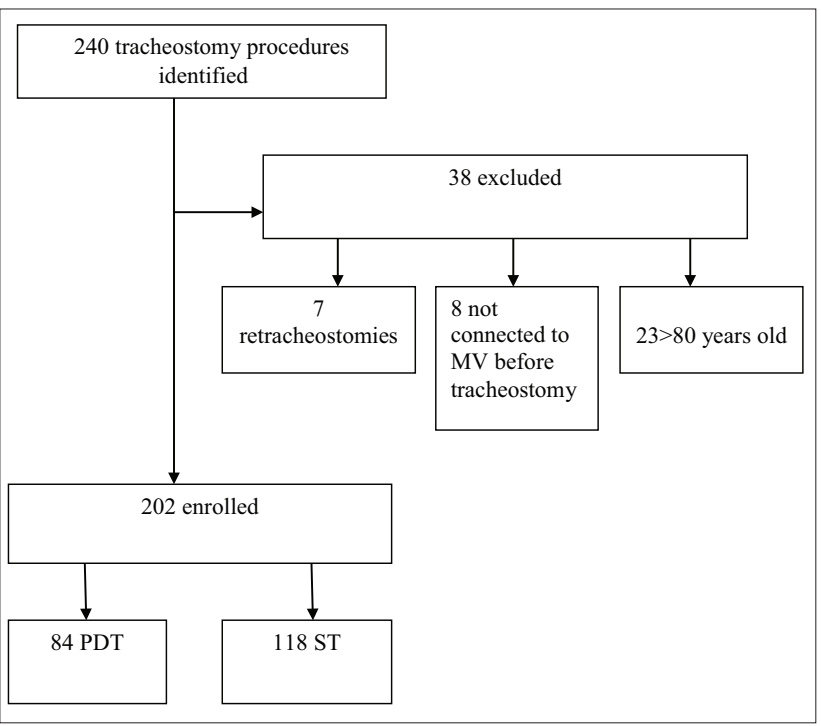

Figure 1. Study protocol
Smiths Medical International Ltd). After PDT a chest Xray to check for tube position was done.

Outcome measures. We measured the following baseline characteristics: age, gender, cause of hospitalization, time to tracheostomy, type of tracheostomy, duration of mechanical ventilation after tracheostomy procedure, overall duration of mechanical ventilation, infections before tracheostomy procedure (pneumonia, urinary tract infection and sepsis) and length of stay in the hospital.

To detect stoma infection, patients records were evaluated for local signs of infection, clinical symptoms (fever), laboratory (C-reactive protein, complete blood count, wound culture if was done) and diagnostic tests reports (CT scan of neck if was done). Stoma site infection was defined according to Center for Disease Control and Prevention (CDC) surgical site infection (SSI) criteria [14].

We also evaluated other complications of tracheostomy procedure including bleeding, pneumothorax, gastric aspiration, false route, subcutaneous emphysema.

Statistical analysis. Data was analysed using the SPSS 20.0 (SPSS Inc., Chicago, IL, USA) statistical package. Data is presented as medians and count/percentage. MannWhitney U-test, Chi-square test (X2) or Fisher's exact test

Table 1. Comparison of PDT and ST groups

Continuous variables are presented as median (min-max) except if stated otherwise. Discrete variables are summarized using percentages $[n(\%)]$ and the differences were tested by $X^{2}$.

*Other: neuromuscular disorder (myastenia gravis, Guillain-Barre syndrome), malignancy related condition, CNS infection, status epilepticus, intoxication, metabolic coma, post-anoxic encephalopathy, ruptured brain aneurysm, spinal trauma or polytrauma.

\begin{tabular}{|c|c|c|c|c|}
\hline Measurements & $\begin{array}{l}\text { All patients } \\
(\mathrm{n}=202)\end{array}$ & PDT $(n=84)$ & ST $(n=118)$ & $\begin{array}{l}\text { p-va- } \\
\text { lue }\end{array}$ \\
\hline Age, years & $60.0(19-80)$ & $57.0(19-80)$ & $62.5(25-79)$ & 0.126 \\
\hline Gender, male, n (\%) & $140(69.3)$ & $65(77.4)$ & $75(63.6)$ & 0.036 \\
\hline $\begin{array}{l}\text { Reasons for ICU admis- } \\
\text { sion } \\
\text { - Isolated traumatic } \\
\text { brain injury, n (\%) } \\
\text { - Stroke, } \mathrm{n}(\%) \\
\text { - Other*, n (\%) }\end{array}$ & $\begin{array}{l}69(34.2) \\
62(30.7) \\
71(35.1)\end{array}$ & $\begin{array}{l}36(42.9) \\
24(28.6) \\
24(28.6)\end{array}$ & $\begin{array}{l}33(28.0) \\
38(32.2) \\
47(39.8)\end{array}$ & 0.028 \\
\hline $\begin{array}{l}\text { Infection before tracheos- } \\
\text { tomy procedure } \\
\text { - Pneumonia, } \mathrm{n}(\%) \\
\text { - Urinary tract infection, } \\
\text { n (\%) } \\
\text { - Sepsis, n (\%) }\end{array}$ & $\begin{array}{c}124(61.4) \\
55(27.2) \\
15(7.4)\end{array}$ & $\begin{array}{c}55(65.5) \\
20(23.8) \\
7(8.3)\end{array}$ & $\begin{array}{c}69(58.5) \\
35(29.7) \\
8(6.8)\end{array}$ & $\begin{array}{l}0.314 \\
0.357 \\
\\
0.678\end{array}$ \\
\hline $\begin{array}{l}\text { Time to tracheostomy, } \\
\text { days } \\
\text { Time of tracheostomy, } \\
\text { days } \\
\text { Duration of mechanical } \\
\text { ventilation (MV), days } \\
\text { Duration of MV after } \\
\text { tracheostomy, days } \\
\text { Hospital stay after trache- } \\
\text { ostomy, days }\end{array}$ & & $\begin{array}{c}9(1-56) \\
17.5(1-63) \\
11(1-40) \\
2(1-27) \\
22(1-63)\end{array}$ & $\begin{array}{c}10(1-49) \\
18(1-147) \\
12(1-161) \\
3(1-147) \\
20.5(1-147)\end{array}$ & $\begin{array}{l}0.084 \\
0.365 \\
0.066 \\
\\
0.067 \\
\\
0.672\end{array}$ \\
\hline
\end{tabular}


were used for analysis where appropriate. Binary logistic regression was performed to test associations of clinical data with stoma infection. A statistical difference was considered significant at the level of $\mathrm{p}<0.05$.

\section{Results}

Patients' characteristics. A total of 240 patients were identified. The data from 202 patients who met the inclusion criteria were used for further analysis. There were 84 patients in PDT group and 118 patients in ST group (Fig.1). Groups were comparable according to age, rate of infections before tracheostomy, and time to tracheostomy. An overall duration of mechanical ventilation, the duration of mechanical ventilation after tracheostomy and hospital stay after tracheostomy did not differ between PDT and ST. (Table 1).

PDT is associated with lower risk for stoma infection. Overall, the incidence rate of stoma infection was significantly lower in PDT group $14(16.7 \%)$ vs. 77 (65.3\%), p $<0.001$ (Fig.2). We performed the logistic regression adjusting for age, sex, cause of hospitalization, tracheostomy strategy and timing of the procedure to calculate odds ratio to illustrate the associations between tracheostomy strategy and stoma infection. We found that ST strategy increased stoma infection probability by 8.83 $(\mathrm{p}<0.001)$ (Table 2).

PDT and ST are comparable in terms of procedure related complications. All other complications during PDT and ST procedures are presented in Table 3. False route was defined as paratracheal insertion of tracheostomy tube. Bleeding was counted only obviously clinically relevant that required surgical exploration, suture ligation and electrocauterization rather than bleeding that resolved spontaneously or with simple pressure. Gastric aspiration

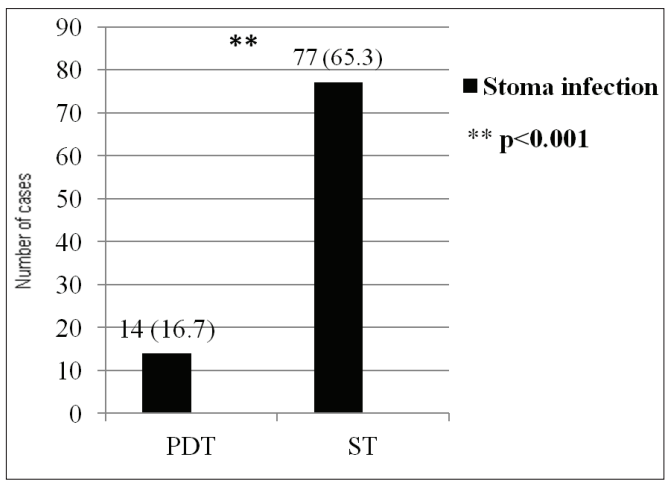

Fig 2. The incidence rate of stoma infection is lower in PDT as compared to ST group

Values are represented as number of patients and percentages [ $n$ $(\%)]$. was considered when gastric contents were aspirated from trachea during the procedure.

\section{Discussion}

The purpose of this study was to identify and compare the presence of stoma infection after tracheostomy according to the type of procedure (PDT vs ST) in the NICU patients. Our results showed that the surgical strategy of tracheostomy presented with an increased rate of stoma infection.

The lower rate of stoma infection with PDT strategy compliances the findings of previous studies [7, 9-11]. A meta-analysis performed in 2006 by Delaney et al. involved 17 randomized controlled trials with 1212 patients reported a significant reduction in the odds ratio for stoma infection when tracheostomy was performed using the PDT compared with the ST strategy $(\mathrm{OR}=0.28 ; 95 \%$ CI 0.16 to $0.49, \mathrm{p}<0.0005)$ [7]. A meta-analysis performed a year later by Higgins and Punthakee also agreed with less wound infections in percutaneous techniques than in open surgical technique. They concluded that there was no clear difference between two strategies but a trend toward fewer complications was in percutaneous techniques compared to open tracheostomy [10]. There was appointed a considerable heterogeneity in the stoma infection definition between studies, however an apparent tendency for less infections were seen in PDT strategy. A prospective single-institutional study performed in 2013 by Park et al. involved 640 critically injured trauma patients treated in the ICU over eight years used the same stoma infection definition as in our study and concluded that patients who underwent percutaneous tracheostomy had a statistically significantly lower rate of stoma infection (3.4\%) than the open surgery group (7\%) [9]. None of these studies was specific for NICU patients.

A lower rate of stoma infection in PDT group could be explained with minimally invasive technique, a very small

Table 2. Presentation of odds ratios for patients with or without stoma infection

Age presented as median (min-max). Other values are represented as number of patients and percentages (calculated for both groups: without stoma infection versus with stoma infection). OR - odds ratio; ${ }^{* *} p<0.001$.

\begin{tabular}{|c|c|c|c|c|}
\hline & $\begin{array}{c}\text { Patients } \\
\text { without } \\
\text { stoma in- } \\
\text { fection }\end{array}$ & $\begin{array}{c}\text { Patients } \\
\text { with } \\
\text { stoma } \\
\text { infection }\end{array}$ & $\begin{array}{c}\text { OR }(95 \% \\
\text { CI) }\end{array}$ & p-value \\
\hline All patients, n (\%) & $111(55.0)$ & $91(45.0)$ & & \\
\hline $\begin{array}{l}\text { Age (years), me- } \\
\text { dian (min-max } \\
\text { Trache o s to my } \\
\text { strategy, n (\%) }\end{array}$ & $57(19-80)$ & $63(20-80)$ & $\begin{array}{c}1.01(0.99 \\
\text { to } 1.03)\end{array}$ & 0.439 \\
\hline $\begin{array}{l}\text { - } \mathrm{PDT} \\
\text { - } \mathrm{ST}\end{array}$ & & $\begin{array}{l}14(16.7) \\
77(65.3)\end{array}$ & $\begin{array}{c}8.83(4.40 \\
\text { to } 17.71)\end{array}$ & $0.000 * *$ \\
\hline
\end{tabular}


Table 3. PDT and ST are comparable in terms of procedure related complications

Discrete variables are summarized using percentages [n (\%)] and the differences were tested by $X^{2}$ or Fisher's exact test.

\begin{tabular}{|l|c|c|c|c|}
\hline Complications & $\begin{array}{c}\text { All pa- } \\
\text { tients } \\
(\mathbf{n = 2 0 2})\end{array}$ & $\begin{array}{c}\text { PDT } \\
(\mathbf{n}=\mathbf{8 4})\end{array}$ & $\begin{array}{c}\text { ST } \\
(\mathbf{n}=\mathbf{1 1 8})\end{array}$ & $\begin{array}{c}\text { p-va- } \\
\text { lue }\end{array}$ \\
\hline Bleeding, n (\%) & $1(0.5)$ & $0(0.0)$ & $1(0.8)$ & 1.000 \\
Pneumothorax, n (\%) & $1(0.5)$ & $1(1.2)$ & $0(0.0)$ & 0.416 \\
Gastric aspiration, n (\%) & $1(0.5)$ & $0(0.0)$ & $1(0.8)$ & 1.000 \\
False route, n (\%) & $2(1.0)$ & $2(2.4)$ & $0(0.0)$ & 0.172 \\
Subcutaneous emphyse- & $1(0.5)$ & $1(1.2)$ & $0(0.0)$ & 0.416 \\
ma, n (\%) & & & & \\
\hline
\end{tabular}

skin incision and blunt dissection which reduces the area available for bacterial colonization and preserves immune functions due to minimized local tissue trauma. PDT also has a tighter fit between cannula and the surrounding tissues $[15,16]$.

The incidence rate of stoma infection highly varies between the studies $[7,9,10]$. Compared to other studies, we found high numbers of stoma infection in both groups: $16.7 \%$ in PDT group and $65.3 \%$ in ST group. Heterogeneity of patients with different severity of critical illness and comorbidities between the studies, different time of tracheostomy procedure (early vs late) and an absence of universal stoma infection definition could be an explanation [7, 9, 17-19]. Park et al. using similar wound infection definition found lower incidence rate of stoma infection in both groups (3.4\% in PDT group versus $7 \%$ in ST group) because the study patients were younger (mean age of 43.2 years) and belonged to a single pathology group compared with our patients [9].

Study limitations. We declare several potential limitations of our study. Firstly, a retrospective study is inevitably associated with selection bias as patients with anatomical difficulties, were more likely to choose for ST and patients with minimal intraprocedural risks were chosen for PDT. Secondly, we could not control data about complications and outcomes assessment but instead of that we need to rely on others for accurate records registration. Compared with previously published studies with a variety of stoma infection definitions, we minimized bias and used widely accepted precise SSI definition.

To our knowledge, this is the first study providing the incidence rate of stoma infection according to tracheostomy strategy among NICU patients in Lithuania. We plan prospective study for NICU patients to avoid patient bias and to make PDT more feasible.

\section{Conclusions}

1. The incidence rate of stoma infection was signifi- cantly higher in ST group compared to PDT group in NICU patients.

2. ST strategy was associated with increased probability for stoma infection compared to PDT.

3. Based on these results, we conclude that PDT at the patients' bedside could be a favourable strategy with similar clinical outcomes to perform tracheostomy for the most NICU patients.

\section{Conflict of interest}

Authors state no conflict of interest.

Author's contributions

$\mathrm{NB}, \mathrm{OK}$ - both authors have equally contributed to the manuscript, study concept and design, interpretation of the results, and drafting of the manuscript, JR was responsible for the preparation of the dataset for the analysis and data analysis, AK ontributed to the interpretation of results and to review the manuscript, TT contributed to the initial study idea, study concept and design.

\section{References}

1. Mallick A, Bodenham AR. Tracheostomy in critically ill patients. Eur J Anaesthesiol 2010 Aug;27(8):676-82.

https://doi.org/10.1097/eja.0b013e32833b1ba0

2. Astrachan DI, Kirchner JC, Goodwin WJ Jr.Prolonged intubation vs. tracheotomy: complications, practical and psychological considerations. Laryngoscope 1988 Nov;98(11):1165-9. https://doi.org/10.1288/00005537-198811000-00003

3. Nieszkowska A, Combes A, Luyt CE, Ksibi H, Trouillet JL, Gibert C, Chastre J. Impact of tracheotomy on sedative administration, sedation level, and comfort of mechanically ventilated intensive care unit patients. Crit Care Med 2005 Nov;33(11):2527-33.

https://doi.org/10.1097/01.CCM.0000186898.58709.AA

4. Kluge S, Baumann HJ, Maier C, Klose H, Meyer A, Nierhaus A. et al. Tracheostomy in the intensive care unit: a nationwide survey. Anesth Analg 2008 Nov;107(5):1639-43. https://doi.org/10.1213/ane.0b013e318188b818

5. Fikkers BG, Fransen GA, van der Hoeven JG, Briedé IS, van den Hoogen FJ. Tracheostomy for long-term ventilated patients: a postal survey of ICU practice in The Netherlands. Intensive Care Med 2003 Aug;29(8):1390-3. Epub 2003 Jul 22.

https://doi.org/10.1007/s00134-003-1824-x

6. Veenith T, Ganeshamoorthy S, Standley T, Carter J, Young P. Intensive care unit tracheostomy: a snapshot of UK practice. Int Arch Med 2008 Oct 25;1(1):21.

https://doi.org/10.1186/1755-7682-1-21

7. Delaney A, Bagshaw SM, Nalos M. Percutaneous dilatational tracheostomy versus surgical tracheostomy in critically ill patients: a systematic review and meta-analysis. Crit Care 2006;10(2):R55.

https://doi.org/10.1186/cc4887 
8. Barbetti JK, Nichol AD, Choate KR, Bailey MJ, Lee GA, Cooper DJ. Prospective observational study of postoperative complications after percutaneous dilatational or surgical tracheostomy in critically ill patients. Crit Care Resusc 2009 Dec;11(4):244-9.

9. Park H, Kent J, Joshi M, Zhu S, Bochicchio GV, Henry S. et al. Percutaneous versus open tracheostomy: comparison of procedures and surgical site infections. Surg Infect (Larchmt) 2013 Feb;14(1):21-3.

https://doi.org/10.1089/sur.2011.059

10. Higgins KM, Punthakee X. Meta-analysis comparison of open versus percutaneous tracheostomy. Laryngoscope 2007 Mar;117(3):447-54.

https://doi.org/10.1097/01.mlg.0000251585.31778.c9

11. Putensen C, Theuerkauf N, Guenther U, Vargas M, Pelosi P. Percutaneous and surgical tracheostomy in critically ill adult patients: a meta-analysis. Crit Care 2014 Dec 19;18(6):544. https://doi.org/10.1186/s13054-014-0544-7

12. Longworth A, Veitch D, Gudibande S, Whitehouse T, Snelson C, Veenith T. Tracheostomy in special groups of critically ill patients: Who, when, and where? Indian J Crit Care Med 2016 May;20(5):280-4. https://doi.org/10.4103/0972-5229.182202

13. Vargas M, Sutherasan Y, Antonelli M, Brunetti I, Corcione A, Laffey JG. et al. Tracheostomy procedures in the intensive care unit: an international survey. Crit Care 2015 Aug 13;19:291. https://doi.org/10.1186/s13054-015-1013-7

14. Centers for Disease Control (CDC). Surgical site infection (SSI) event. Available at: http://www.cdc.gov/nhsn/PDFs/ pscManual/9pscSSIcurrent.pdf. Accessed December 22, 2016.

15. Targarona EM, Balagué C, Knook MM, Trías M. Laparoscopic surgery and surgical infection. Br J Surg. 2000 May; 87(5):53644.

https://doi.org/10.1046/j.1365-2168.2000.01429.x

16. Buunen M, Gholghesaei M, Veldkamp R, Meijer DW, Bonjer HJ, Bouvy ND. Stress response to laparoscopic surgery: a review. Surg Endosc 2004 Jul;18(7):1022-8.

https://doi.org/10.1007/s00464-003-9169-7

17. Griffiths J, Barber VS, Morgan L, Young JD. Systematic review and meta-analysis of studies of the timing of tracheostomy in adult patients undergoing artificial ventilation. BMJ 2005 May 28;330(7502):1243.

https://doi.org/10.1136/bmj.38467.485671.E0

18. Zheng Y, Sui F, Chen XK, Zhang GC, Wang XW, Zhao S. et al. Early versus late percutaneous dilatational tracheostomy in critically ill patients anticipated requiring prolonged mechanical ventilation. Chin Med J (Engl). 2012 Jun;125(11):1925-30.

19. Lee JC, Fink MP. Early percutaneous dilatational tracheostomy leads to improved outcomes in critically ill medical patients as compared to delayed tracheostomy. Crit Care 2005;9:E12.

https://doi.org/10.1186/cc3759

\section{STOMOS INFEKCIJOS DAŽNIS PO PERKUTANINĖS DILATACINĖS IR CHIRURGINĖS TRACHEOSTOMOS OPERACIJŲ NEUROCHIRURGIJOS INTENSYVIOSIOS TERAPIJOS SKYRIUJE}

N. Balčiūnienė, O. Kriukelytė, J. Ramšaitė, A. Krikščionaitienė, T. Tamošuitis

Raktažodžiai: tracheostomija, perkutaninè dilatacinè tracheostomija, stomos infekcija, intensyvi terapija.

Santrauka

Tikslas: įvertinti ir palyginti stomos infekcijos dažnị po perkutaninès dilatacinès tracheostomijos (PDT) ir chirurginės tracheostomijos (ChT) operacijų neurochirurgijos intensyviosios terapijos skyriuje (NITS).

Medžiaga ir metodai. Atliktas stebimasis retrospektyvinis, kohortinis tyrimas Lietuvos sveikatos mokslų universiteto ligoninès Kauno klinikų (LSMUL KK) Neurochirurgijos intensyviosios terapijos skyriuje. Buvo išanalizuotos NITS pacientų, kuriems buvo atlikta tracheostomos suformavimo operacija nuo $2012 \mathrm{~m}$. spalio mèn. iki 2015 m. gruodžio mèn., ligos istorijos. Tracheostomos suformavimo operacija buvo atlikta 240 pacientų, tačiau įtraukimo ị tyrimą kriterijus atitiko 202 pacientai (iš jų 140 vyrų), kurių amžiaus mediana 60 (19-80) metų. 84 pacientams buvo atlikta PDT, o 118 pacientų atlikta ChT. Abi grupès palygintos.

Rezultatai. Stomos infekcijos dažnis reikšmingai mažesnis PDT grupeje lyginant su ChT grupe: 14 (16,7\%) ir 77 (65,3\%), $\mathrm{p}<0,001$. Taikant regresinę analizę nustatyta, kad ChT atlikimo būdas didina stomos infekcijos riziką 8,83 karto $(\mathrm{OR}=8,83 ; 95 \%$ CI 4,40-17,71; $\mathrm{p}<0,001)$.

Išvados. Nustatytas reikšmingai didesnis stomos infekcijos dažnis ChT grupejje lyginant su PDT grupe NITS pacientų grupejje. ChT atlikimo tipas susijęs su didesne stomos infekcijos tikimybe lyginant su PDT.

Adresas susirašinėti: balciunieneneringa@gmail.com

Gauta 2017-02-25 